\title{
Oysters and Pearls - or Coffee and Cars?
}

\author{
O Oysters,' said the Carpenter, \\ You've had a pleasant run! \\ Shall we be trotting home again?' \\ But answer came there none - \\ And this was scarcely odd, because \\ They'd eaten every one.
}

\author{
The Walrus and the Carpenter \\ Lewis Caroll
}

\section{A Pearly Anniversary}

On $25^{\text {th }}$ of September the General Court celebrated its $30^{\text {th }}$ anniversary. If this had been a wedding anniversary it would have been a pearl anniversary. The traditional symbol for the $30^{\text {th }}$ wedding anniversary is the pearl. A pearl is considered a symbol of beauty which is cultivated over time as it grows within its oyster. The oyster shell itself is considered ugly compared to the pearl which lays inside it and this can be thought of in the same way as a thirty-year marriage.

The General Court celebration was of course a serious event with a serious programme adorned with various pearls of topical importance and around the central theme of the General Court in the Digital Age. Notably absent from the event was one particularly ugly shell the Treaty State aid regime. This is perhaps surprising given that the judges of the General Court devote a considerable portion of their deliberations to Article 107(1) TFEU. Moreover, the day before its Seventh Chamber (Extended Composition) had handed down the first four rulings on the controversial tax ruling cases. With six more to follow in the near future, this first batch of oysters were eagerly awaited, and no doubt by the Commissioner herself. She has pledged to continue her campaign for fair taxation into her second mandate. The European Parliament will no doubt pursue this topic during the hearings on the appointment of the proposed new Commissioners. But perhaps the judges had no appetite for the slippery slimy crustacean on their festive occasion - safe in the knowledge that there are many more cases to come.

\section{Did the Ugly Oysters Reveal any Anniversary Pearls?}

Not all individual oysters produce pearls naturally. Apparently in a harvest of two and a half tons of oysters, only three to four oysters produce what commercial buyers consider to be absolute perfect pearls. On the $24^{\text {th }}$ of September the harvest comprised of four rulings, but did they reveal any pearls? The General Court (the Court) upheld the European Commission's (Commission) ruling ordering Luxembourg to recover €23.1 million from Fiat and annulled the Commission's ruling ordering the Netherlands to recover $€ 25.7$ million from Starbucks. ${ }^{1}$

DOI: $10.21552 / \mathrm{estal} / 2019 / 3 / 2$

1 Joined Cases T-760/15 and T-636/16 Kingdom of the Netherlands v European Commission (Starbucks) [2019] ECLI:EU:T:2019:669; Joined Cases T-755/15 and T-759/15 Grand Duchy of Luxembourg v European Commission (Fiat Chrysler) [2019] ECLI:EU:T:2019:670. 
As these rulings will be the subject of detailed commentary and analysis by tax law as well as State aid law experts in the coming months, given that the Seventh Chamber confirmed one Decision and annulled the other, it will be interesting to see which judgments if any, are to be considered to contain at very least the seeds of a pearl? Obviously, the answer to that question will depend on whether one applauds the application of the State aid rules to taxation issues. The two governments seeking annulment as well as those intervening in their support (the UK and Ireland) will not have been pleased to learn that the General Court rejected all their more principled objections to the application of Article 107(1) TFEU as a form of disguised tax harmonisation and an invasion of sovereign powers. The Grand Duchy of Luxembourg had claimed the Commission had established itself as a national tax administration appeal chamber by reviewing whether its tax ruling in favour of Fiat Chrysler Finance Europe (FFT) was abnormal having regard to Luxembourg law and the OECD rules on the arm's length principle. The GC curtly dismissed that line of argument, recalling that if a measure discriminates between companies in a comparable situation regarding the objective of the tax and as a result it confers a selective advantage as the Commission was just doing its job. It was within its powers to determine 'normal' taxation as the taxation of an integrated undertaking - irrespective of actual national treatment of multinational groups. In doing so it had not created legal uncertainty -either in the EU or in third countries, nor had it ridden roughshod over the legitimate expectations of the recipients of tax rulings. In FFT the General Court upheld the Commission's principal line of reasoning that the tax ruling derogated from the general Luxembourg corporate income tax system.

It confirmed the Commission's power to compare the fiscal burden imposed on an integrated undertaking resulting from the contested fiscal measure with the fiscal burden resulting from the application of the normal rules of national taxation under the national law of an undertaking placed in a comparable situation and carrying on its activities under market conditions. Article 107(1) allows the Commission to check whether the pricing of intra-group transactions corresponds to market conditions. The arm's length principle is the very tool for making that determination. The same line of reasoning is essentially applied in the Starbucks case.

In its application of the tool the Commission had rightly found in the FFT case that the methodology used for calculating FFTs remuneration did not enable an arm's length remuneration to be obtained, resulting in a reduction of FFT's taxable profit. Furthermore, given that the tax ruling was an ad hoc or individual aid measure, once it had been established that it conferred an economic advantage on FFT, there was a presumption that it was selective. It was up to the Grand Duchy to rebut that presumption, inter alia, by demonstrating that the derogation from the 'normal' tax rules could be justified by the logic of the system.

In Cases T-760/15 and T-636/16 - Starbucks - however, the Commission had not established that the coffee company SMBV (part of the Starbucks group responsible for roasting coffee), had enjoyed an economic advantage and so there was no need to consider selectivity. The Netherlands and Starbucks had criticised the Commission for having erroneously considered the choice of the transactional net margin method (TNMM) for determining SMBV's remuneration as a basis for calculating its corporate income tax and for having erroneously considered the detailed rules for the application of that method as validated in its advance pricing arrangement (APA) to constitute an economic advantage. The General Court upheld those claims - the mere non-compliance with methodological requirements does not necessarily lead to a reduction of the tax burden and that the Commission would have had to demonstrate that the methodological errors identified in the APA did not allow a reliable approximation of an 
arm's length outcome to be reached and that they led to a reduction of the tax burden. As regards the error identified by the Commission in respect of the choice of the TNMM and not of the 'CUP method', the Court finds that the Commission did not invoke any element to support as such the conclusion that that choice had necessarily led to a result that was too low, without a comparison being carried out with the result that would have been obtained using the CUP method. The Commission therefore wrongly found that the mere choice of the TN$\mathrm{MM}$, in the present case, conferred an advantage on SMBV. The mere finding by the Commission that the APA did not analyse the royalty does not suffice to demonstrate that that royalty was not actually in conformity with the arm's length principle. As regards the amount of the royalty paid by SMBV to its Swiss subsidiary - Alk - , according to an analysis of SMBV's functions in relation to the royalty and an analysis of comparable roasting agreements considered by the Commission, the Court held that the Commission failed to demonstrate that the level of the royalty should have been zero or that it resulted in an advantage within the meaning of the Treaty. It had faulted the Dutch authorities for not analysing a royalty paid by one Starbucks subsidiary to another, without undertaking its own assessment of whether the royalty complied with the arm's length principle.

\section{And Have They Eaten Every One?}

It is of course too early to predict whether any new pearls have emerged from this line of case law. Neither Luxembourg, FFT nor the Commission have announced whether they will appeal the 24 September rulings. The General Court has endorsed the major steps in the Commission's application of Article 107(1) to tax ruling practice so far. It has fully endorsed the tools that the Commission has fashioned for itself in the process. At the same time, it has been vigilant in ensuring that those tools are applied consistently and correctly to the facts at hand. In conclusion, the Court is broadly supportive of the Commission's approach in its State aid investigations into tax rulings subject to a fairly rigorous standard of proof. This is likely to embolden the Commission in its approach to State aid taxation cases. The Commissioner may not have been adorned with a full string of pearls - yet!

Leigh Hancher 